\title{
マルチコアPCクラスタにおける電力系統シミュレーションの並列化手法の検討
}

\author{
上級会員 田岡 久雄* 非会員 藤田 雄一*

\section{Parallel Power System Simulation on a Multi-Core PC Cluster}

Hisao Taoka*, Senior Member, Yuichi Fujita*, Non-member

This letter describes a parallel solution method of power system transient stability analysis on a multi-core PC cluster system. We use a cash blocking method for solving differential equations and simultaneous equations. This method can use multi-core PC cluster efficiently by dividing matrix calculation of differential equations and simultaneous equations of power system simulation into cash size of each core.

キーワード: 電力系統解析, PC クラスタ, シミュレーション, マルチコア, 並列処理

Keywords: power system analysis, PC cluster, simulation, multi-core, parallel processing

\section{1. まえがき}

電力系統のシミュレーションの高速化に対する要求は系 統が複雑高度になるにつれますます高くなっており，さま ざまな計算手法とコンピュータの適用が試みられている。

PCクラスタによる電力系統解析の高速化は, 瞬時值計算 においては進行波の遅延を利用し, 送電線で系統分割する ことにより並列化を行って, リアルタイムシミュレーショ ンを実現している(1)。一方，実効值解析は，ネットワーク方 程式の求解を並列化して精度良く高速に実行することが難 しく, 従来のリアルタイムシミュレータ(2)(3) においては $1 つ$ の CPU に回路網方程式の求解を担当させ，微分方程式を発 電機母線毎に各 CPUに割り当てることで高速化を実現した り, 改良した逐次代入法で通信量を減らす工夫をしている。

本レターでは, 最近普及し始めたマルチコア CPUを PC クラスタに使用し(4)，CPUのキャッシュの先読み機能のた めに開発されたキャッシュブロック化手法を，微分方程式 及び回路網方程式の求解に適用して, マルチコア CPUの アーキテクチャを生かした電力系統シミュレーションの並 列化を行う手法を提案している。

\section{2. 演算の並列化}

マルチコア CPU とは，一つのチップ上に複数のコアを集 積したものである。コアには，命令制御部，演算部，キャッ シュメモリ部があり，1つの CPUの機能を持っている。コ アの数に応じて複数の演算を同時に実行出来ると共に，一 つのチップ上に集積されているため, 高速で遅延の少ない 経路を取る事ができる ${ }^{(5)}$ 。マルチコアには，図 1 に示すよ

\footnotetext{
*福井工業大学

干 910-8505 福井市学園 3-6-1

Fukui University of Technology

3-6-1, Gakuen. Fukui 910-8505
}

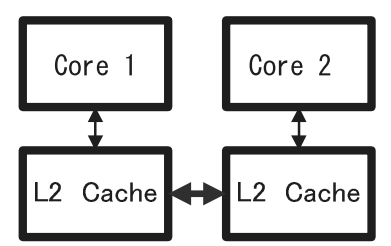

(a) Independent cash type

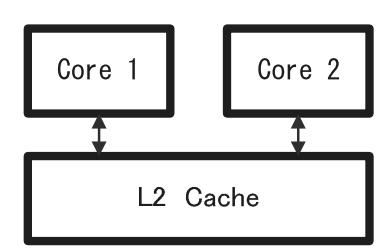

(b) Common cash type
図 1 マルチコア CPU

Fig. 1. Multi-core CPU.

うに, 2 次キャッシュをコア毎に持つものと共通に持つもの がある。通信をキャッシュ間のバスで行うか, キャッシュ を使って行うかの違いはあるが，共に複数の処理が同時に 行われ, 必要に応じて通信しながら処理を進めるため, デー 夕を全てキャッシュ内に収める必要がある。

そこで, データをキャッシュ内に収め, 複数のコアに処 理を分担させる方法として, CPUのキャッシュの先読み機 能のために開発されたキャッシュブロック化手法を, 行列 計算に適用することを提案する。

行列積の演算を $\mathrm{C}$ 言語で実装した場合を，以下に示す。

$$
\begin{aligned}
& \text { for }(i=0 ; i<n ; i++) \\
& \qquad \begin{array}{l}
\text { for }(j=0 ; j<n ; j++) \\
\quad \text { for }(k=0 ; k<n ; k++) \\
\quad C[i][j]+=A[i][k] * B[k][j] ;\}\}\}
\end{array}
\end{aligned}
$$

これは，nが大きくなると図 2(a) に示すように，配列 $\mathrm{A}$ ， B , Cのデータがキャッシュに収まらなくなる。そこで, 下記 のコードに書き換えることで, データをキャッシュ内に収ま るサイズに抑えることができ，演算は図 2(b) のように進む。

$$
\mathrm{ibl}=16 ; \text { for }(i b=0 ; i b<n ; i b+=i b l)\{
$$




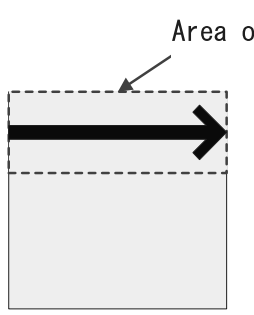

Matrix C

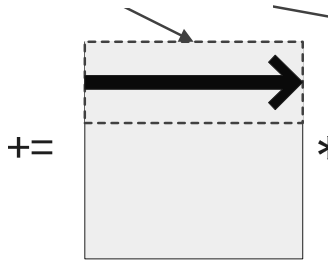

Matrix A

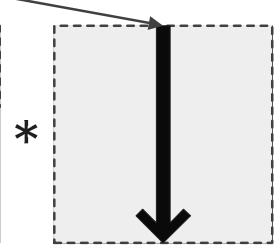

Matrix B (a) Without blocked method

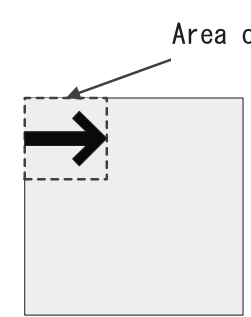

Matrix C

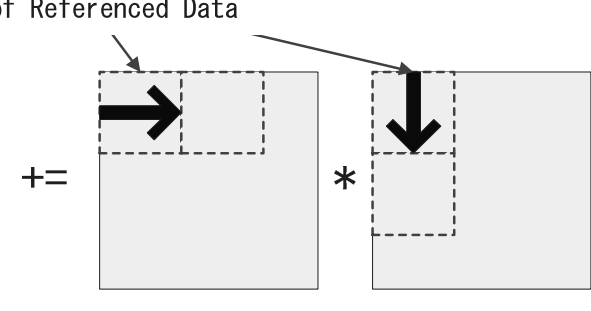

Matrix A

Matrix B (b) With blocked method

図 2 行列計算の並列化

Fig. 2. Parallel solution of matrix.

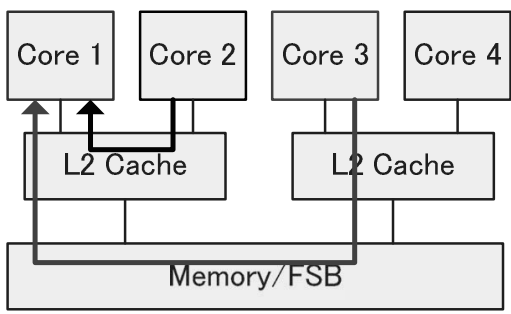

$\longleftarrow$ Large Delay

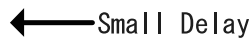

図 3 マルチコアCPUのメモリ構造

Fig. 3. Memory structure of multi-core CPU.

$$
\begin{aligned}
& \text { for }(j b=0 ; j b<n ; j b+=i b l)\{ \\
& \text { for }(k b=0 ; k b<n ; k b+=i b l)\{ \\
& \text { for }(i=i b ; i<i b+i b l ; i++)\{ \\
& \text { for }(j=j b ; j<j b+i b l ; j++)\{ \\
& \quad \text { for }(k=k b ; k<k b+i b l ; k++)\{ \\
& \qquad C[i][j]+=A[i][k] * B[k][j] ;\}\}\}\}\}\}
\end{aligned}
$$

ibl の值を調節すればデータを常に各コアのキャッシュサイ ズ以下に収めることが出来る。これはキャッシュブロック 化 ${ }^{(6)}$ と呼ばれ，CPUのキャッシュを先読みする機能である が，各コアへの演算処理の分割に用いることで，大きな行 列計算の並列化を行うことができる。

コア数の大きいクアッドコア CPU では，図 3 のように， 2 コア毎に 2 次キャッシュが分かれており，メモリ構成が階 層構造になるが，上記の方法で効率よく並列化できる。マ ルチコア CPU 搭載の PC を使用したマルチコア PC クラス 夕の各 $\mathrm{PC} へ$ 実装は, 密な通信が必要なものは同一 $\mathrm{CPU}$ 内のコアに，疎な通信の場合は別 CPUに割り当てる。

3. 電力系統シミュレーション

実装するに際し共有メモリ並列プログラミングの標準 API である Open MP を使用し，ブロック化キャッシング手法
表 1 行列積の計算の処理時間の比較（Dual Core 1 CPU） Table 1. Processing time of matrix multiply (Dual Core $1 \mathrm{CPU}$ ).

\begin{tabular}{|l|c|c|}
\hline Size & without Blocked Method & with Blocked Method \\
\hline 50Gen. System & $9.82[\mathrm{msec} / \mathrm{step}]$ & $5.74[\mathrm{msec} / \mathrm{step}]$ \\
\hline 200Gen. System & $41.21[\mathrm{msec} / \mathrm{step}]$ & $19.32[\mathrm{msec} / \mathrm{step}]$ \\
\hline
\end{tabular}

を用いて書き換えたシミュレーションプログラムの一部を コンパイルし実行した。キャッシュサイズの範囲内に調節 することで, 表 1 に示すように処理時間をキャッシュサイ ズを超えた場合に比べて約半分に抑えることができた。

今回, 微分方程式の求解には代数方程式化手法 (7) を用い, 回路網方程式の求解にはガウスの消去法 ${ }^{(8)}$ を用い, 前述の キャッシュブロック化手法で行列計算を並列化している。

4. まとめ

本レターでは, マルチコア CPU を PC クラスタに使用し, キャッシュブロック化による並列化手法を電力系統シミュ レーションに適用して, マルチコア CPU のアーキテクチャ を生かした電力系統シミュレーションの並列化を行う手法 を提案した。今後シミュレータとして完成を目指したい。

(平成 21 年 4 月 1 日受付，平成 21 年 5 月 15 日再受付)

$$
\text { 文献 }
$$

(1) T. Yamamaoto, H. Enomoto, K. Kuroda, Y. Kono, and H. Taoka: "Real Time Power System Simulator on PC Cluster", IEEJ Trans. PE, Vol.124, No.5, pp.733-740 (2004-5) (in Japanese)

山本隆也·榎本 博 - 黒田憲一 ·河野良之 ·田岡久雄：「PCクラ スタによるリアルタイム電力系統シミュレータ」, 電学論 $\mathrm{B}, \mathbf{1 2 4}, 5$, pp.733-740 (2004-5)

(2) H. Taoka, I. Iyoda, H. Noguchi, N. Sato, and T. Nakazawa: "Real-Time Digital Simulator for Power System Analysis on a Hypercube Computer", IEEE Trans. Power Syst., Vol.PWRS-7, No.1, pp.1-10 (1992)

(3) N. Sato, T. Nakazawa, A. Yamasaki, H. Taoka, I. Iyoda, and H. Noguchi: "Digital Real Time Simulator for Power System Analysis", T. IEE Japan, Vol.113-B, No.8, pp.855-864 (1993-8) (in Japanese) 佐藤信之 · 中澤太郎 - 山崎 彰 - 田岡久雄 - 伊与田功 - 野口秀夫 : 「ディジタル型リアルタイム系統解析シミュレータの開発」, 電学論 B, 113, 8, pp.855-864 (1993-8)

(4) Y. Fujita and H. Taoka: "Installation Method of Software on Multi-Core PC Cluster", 2008 Joint Conference of Hokuriku Chapters of Electrical Societies, No.E-76 (2008) (in Japanese)

藤田雄一・田岡久雄：「マルチコア CPU を組み込んだ PC クラスタ のソフトウェア実装方法に関する研究」, 平成 20 年電気関係学会北 陸支部連合大会, No.E-76 (2008)

(5) K. Matsuzaki and M. Takeichi: "Introduction to Multicore Environments and Parallelization Techniques", IPSJ Magazine, Vol.49, No.12, pp.13631368 (2008) (in Japanese)

松崎公紀・武市正人：「マルチコア計算機と基本的な並列化技法」, 情 報処理, 49, 12, pp.1363-1368 (2008)

(6) T. Katagiri: "Intelligent Programming (I) Basic Version", Super Computing News, University of Tokyo, Vol.10, No.4 (2008) (in Japanese) 片桐孝洋 :「高性能プログラミング (I) 入門編」, 東京大学情報基盤 センター,スーパーコンピューティングニュース, 10, 4 (2008)

(7) H. Taoka and S. Abe: "Fast Transient Stability Analysis Suited for an Array Processor", T. IEE Japan, Vol.104-B, No.5, pp.297-304 (1984-5) (in Japanese)

田岡久雄・阿部 茂:「アレイプロセッサに適した高速過渡安定度 計算手法」, 電学論 B, 104, 5, pp.297-304 (1984-5)

(8) H. Taoka and S. Abe: "Fast Solution Method of Simultaneous Linear Equations for Pipeline Operation and Its Application to Power System Analysis", T. IEE Japan, Vol.105-B, No.5, pp.419-426 (1985-5) (in Japanese) 田岡久雄・阿部 茂:「パイプライン処理に適した連立一次方程式の高 速求解法とその電力系統解析への応用」, 電学論 B, 105, 5, pp.419-426 (1985-5) 